\title{
Research
}

\section{Modification of Land Cover in a Traditional Agroforestry System in Spain: Processes of Tree Expansion and Regression}

\author{
$\underline{\text { Tobias Plieninger }}^{1}$ and $^{\text {Michael Schaar }}{ }^{2}$
}

\begin{abstract}
Europe's traditional cultural landscapes have undergone significant land-use and land-cover changes in the past $50 \mathrm{yr}$. Land-cover inventories facilitate the quantification of the conversion from one land-cover unit to another. However, they often fail to detect fine-grained modifications that occur within one land-cover category. This study aims to detect such land-cover modification at two farms within dehesas, a traditional agroforestry system in Spain. The focus is on the dynamics of holm oak (Quercus ilex) stands as the key landscape element of dehesas. Aerial photography and satellite imagery were used to measure tree expansion and regression between 1956 and 1984, and between 1984 and 2003. With < $0.01-0.03 \%$ of the tree cover recruited per year, current recruitment seems too low by a factor of 10 to 50 to maintain existing stand densities. Recruitment rates between 1956 and 2003 were slightly higher, but loss rates were dramatically higher on privately owned land compared to common property. Although higher grazing pressure on common property may have inhibited recruitment, the complexity of land tenure can act as a barrier to forest clearing. The synopsis of high loss rates from 1956 to 1984, low loss rates from 1984 to 2003, and low recruitment rates over both periods indicates that deliberate oak cutting has stopped, but that the problem of regeneration failure still remains unresolved. The analysis of oak expansion and regression as a precursor of land conversion can provide a powerful tool for subtle structural changes and can be used as an early warning system before conversion becomes visible.
\end{abstract}

Key Words: landscape changes; landscape structure; Quercus ilex; traditional landscape; tree regression

\section{INTRODUCTION}

With the emergence of global environmental change on the political and research agenda, the study of landscape dynamics has intensified, leading to the foundation of a "landscape science" (Klijn and Vos 2000) or "land use science" (Rindfuss et al. 2004) that integrates social, natural, and geographic information sciences. As in other regions of the world, Europe's countryside has undergone significant land-use and land-cover changes throughout its history. The rate and magnitude of these changes have greatly accelerated since the end of World War II. This rapid change has endangered the persistence of many traditional cultural landscapes that are defined as "landscapes with a long history, which evolved slowly and where it took centuries to form a characteristic structure reflecting a harmonious integration of abiotic, biotic and cultural elements" (Antrop 1997). Such landscapes are both culturally important and significant hotspots of biodiversity (Eichhorn et al. 2006). Structural disruption led to the simplification and standardization of traditional landscapes and finally to a loss of many unique landscape values and resources (Poudevigne and Alard 1997, Antrop 2004, Plieninger et al. 2006). These landscape changes are driven by complex interactions of socioeconomic, political, technological, natural, and cultural factors (Brandt et al. 1999). In the case of Europe's traditional farmland, a vulnerable agricultural economy and rural depopulation have triggered a polarization of land use between intensification and extensification/marginalization, which can both be harmful for the cultural and biodiversity values of landscapes (Meeus et al. 1990, Kristensen 1999).

Tools for the quantitative assessment of landscape changes are needed for both scientific and practical purposes. Fortunately, general reference systems for landscape inventories, e.g., the CORINE 
program of the European Union or the FAO landcover classification system (LCCS), are now widely available (Feranec et al. 2007). For example, it has been confirmed that approximately 1.4 million ha of low-intensity farmland in Spain were converted to irrigation in the 1970s and 1980s (Bignal and McCracken 1996). However, the relationship between land cover and land use remains complex and poorly understood (Jansen and Di-Gregorio 2002). One problem common to higher-scale assessments is that they grasp only coarse-grained transitions from one land-cover unit to another, e. g., from grassland to cropland. These approaches are often highly generalized and thus fail to detect fine-grained, subtle modifications that occur within the same category (Bunce et al. 2005). For example, Kizos and Koulouri (2008) have demonstrated the enormous structural distinctions that are subsumed under the broad land-cover category "olive plantation." Modifications within a land-cover category may be as significant for the ecological functions, production potential, and symbolic value of landscapes as land-cover conversion itself. Therefore, there is a need to complement studies of landscape change through more local forms of analysis to calibrate the explanatory power of largescale assessments of land-use and land-cover change (compare Sevenant and Antrop 2007).

\section{Landscape dynamics in Mediterranean dehesas}

The focus of this study is on dehesas, a traditional, low-input, extensive agroforestry system (Meeus 1995) composed of open, heterogeneous canopies of holm oak (Quercus ilex) and cork oak (Q. suber) with a shrub or annual herbaceous understorey (Pereira and da-Fonseca 2003). Dehesas are estimated to cover about 3.1 million ha in the southwest of the Iberian Peninsula (Díaz et al. 1997). They are understood both as a biophysical object and as a purpose for which land is used, i.e., both as a land-cover and land-use class, sensu Feranec et al. (2007). The traditional dehesa system combines extensive livestock grazing of sheep, hogs, goats, cattle, and bulls with the cultivation of oats, barley, and wheat and various forestry uses such as acorns, cork, charcoal, and firewood. Dehesas are generally bound to areas in which large, private landholdings, the so-called latifundios, predominate. Some $90 \%$ of these dehesas are in private ownership in the form of estates that average approximately 500 ha. However, there are also forms of common dehesa tenure. This ancient system is called "dehesa boyal" and dates from the 17 th century or earlier.

Dehesas support a rich biological diversity that evolved from the ingenious and dynamic adaptation of humans to their environment. Therefore, dehesas have been considered to "serve as a guide to future development in Europe" (Meeus 1995) and a potential "globally important agricultural heritage system" (Harrop 2007). However, they have been facing severe landscape changes both on a large and a small scale that have been taking them toward intensification and extensification at the same time (Pinto-Correia and Mascarenhas 1999). Rural historians point out that dehesas have been an inherently dynamic land-use system throughout history (Linares-Luján and Zapata-Blanco 2002). However, the point is often made that the pace of change has accelerated greatly within the period of the socioeconomic "crisis of traditional agriculture" that has been affecting the Spanish countryside since the 1950s (Comins et al. 1993). The prices of traditional agricultural products drifted down, an epidemic of African swine fever threatened traditional hog husbandry, and large parts of the rural population abandoned the countryside (PérezDíaz 1993, Díaz et al. 1997).

\section{Policies governing dehesas}

Policies at regional, national, and European scales have been the main driving force behind both agricultural intensification and land abandonment since the 1980s. The most influential force has been the Common Agricultural Policy (CAP) of the European Union, which supported the production of cereals and cattle, sheep, and goat husbandry in the dehesas. In recent years, agricultural support was gradually decoupled from agricultural production. Parallel to the general financial scheme of the CAP, a set of "accompanying measures," including agri-environmental and afforestation schemes, was introduced in 1992. The aim of the agri-environmental programs was to promote environmentally compatible production processes. The regional government of Extremadura designed a set of "horizontal schemes" applicable to the whole surface and several "zonal schemes" that refer only to specific areas, usually around nature reserves. Horizontal schemes include extensification, organic farming, preservation of indigenous livestock breeds, and agri-environmental training. Zonal schemes can encourage livestock stocking 
rate reduction, reduction of fertilizer inputs, or the conversion of arable land into extensive grassland. The aim of the afforestation schemes is to convert agricultural into forest surfaces. A landmark at the regional level was the 1986 "Ley de Dehesas de Extremadura," a law that aimed to maintain employment on dehesas and increase productivity by restricting clearing to a minimum tree density of 30/ha, instituting regular pruning, and prescribing minimum livestock stocking levels. Accompanied by a general rise in environmental awareness in Spain in the last $20 \mathrm{yr}$ and a growing interest in sustainable regional development and eco-tourism, public intervention at the regional, national, and European levels has started to complement production-oriented schemes with more conservationoriented features.

\section{Dehesa conversion and modification}

When dehesas became increasingly unprofitable in the 1960s and 1970s, a period of uncontrolled economic development triggered the conversion of many dehesas into other types of land cover such as irrigated land, eucalyptus plantations, artificial water bodies, or industrial units (Joffre et al. 1999). Because of the lack of a firm definition of dehesas, there are no comprehensive analyses of conversion rates over the whole dehesa area in Spain and Portugal. It is estimated, however, that some 1 million ha were converted into other land-cover classes between 1950 and 1980 (Eichhorn et al. 2006). The loss of dehesas is said to have been curbed since the 1980s as a consequence of increased conservation awareness, the introduction of stricter conservation legislation, and changes in the allocation of agricultural and regional development funds, although there are arguable estimates of another 600,000-ha decline from 1985 to 1998 (Eichhorn et al. 2006). Although these landcover changes seem to have slowed, the dehesa system continues to be affected by gradual smallscale landscape modifications (Eichhorn et al. 2006). These are basically a consequence of the simplification of the once complex and diverse landuse system that was an adaptation to the economic crisis. In many dehesa estates, oak stands were thinned to facilitate the use of farm machinery, labor-intensive traditional uses such as seasonal livestock movements or tree pruning were abandoned, and shepherds were replaced by fences. Traditional cereal production was also abandoned, and subsequent bush encroachment reduced pasture value (Díaz et al. 1997, Eichhorn et al. 2006). Most farms lost their self-sufficiency and became dependent on introduced feedstuffs, seeds, fertilizers, and pesticides (Campos-Palacín 1984). Because the appropriate land-cover class for dehesas is, in the case of the CORINE land-cover nomenclature, "agro-forestry area," a broad range of biophysical structures and different forms of land uses fall under one common land-cover unit. Landless villagers used dehesas as a grazing resource for working animals.

\section{Scattered holm oaks as key landscape elements}

Probably the most relevant modification of the dehesas is the regression of tree cover (Montero et al. 1998, Plieninger et al. 2003). Scattered holm oaks in dehesas deliver such important services to many other species and to the ecosystem as a whole that they have been described as "ecosystem engineers" (Díaz et al. 2003). They improve soil fertility, microclimate, and soil water-holding capacity (Moreno et al. 2007, Moreno-Marcos et al. 2007) and support an astounding diversity of plant and animal life (Díaz et al. 2003). Oaks have been reported to regenerate insufficiently in most dehesas, so that the long-term persistence of these systems seems to be in doubt, even if outright destruction through land-cover conversion has largely been stopped. This regeneration failure has been interpreted as an inherent problem of livestock grazing in dehesas (Pulido et al. 2001, 2002, Plieninger et al. 2003). In the long run, this regeneration failure may lead to a conversion of dehesas into treeless grasslands, but large-scale monitoring of land cover will only reveal this change decades after it has already taken place.

\section{Objectives}

The overall objective of this study is to detect modifications in the landscape structure at the farm level within the dehesas. The focus is on the analysis of holm oak trees. On the basis of a multitemporal remote-sensing survey, changes in tree density in 1956,1984 , and 2003 were determined. In this study we not only report density changes but also track the life histories of individual trees. Using these data, recruitment and mortality rates can be calculated, which may contribute to a better understanding of the dimension and the underlying 
Fig. 1. Location of the Dehesa Boyal (DB) site in the west and the Parapuños de Doña María (PA) site in the east.

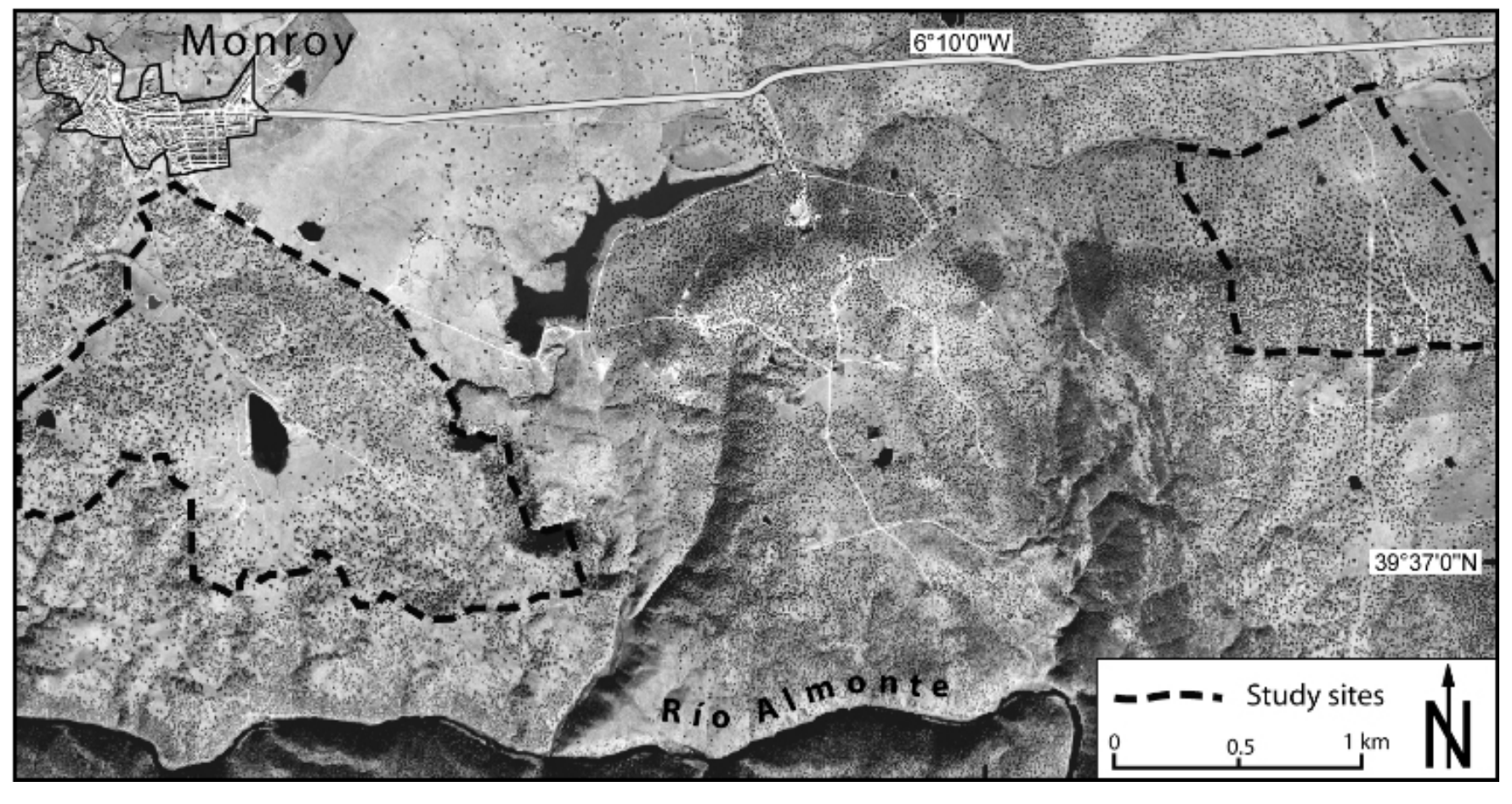

processes of oak regeneration failure. In this context, regeneration is understood as the dynamic process of stand renewal. It is the result of the balance of oak recruitment and mortality in a given stand. The study includes a period of structural and productive reforms in agriculture (1956-1984) and a period of the influence of the market economy and European Union agricultural policies (1984-2003; Calvo-Iglesias et al. 2006) and compares the situation of different actors and institutions involved, i.e., a private and a public farm, which makes it easier to discuss the data in their respective temporal and socio-political contexts.

\section{STUDY AREA}

We selected two distinct areas within two estates called Dehesa Boyal (DB) and Parapuños de Doña María (PA; Fig. 1). They represent the two dominant forms of land tenure in the area. The PA estate is a typical representative of the prevailing system of large private landholdings, whereas the DB estate shows a heterogeneous land-tenure and land-use pattern because it is used in common by the local population.

Both areas are included in the municipality of Monroy in the Extramadura region of southwestern Spain (344' N, 6 13 ' W), which occupies 204.45 $\mathrm{km}^{2}$ of gently rolling (slope: $2-4 \%$ ) lowlands at an altitude of about $378 \mathrm{~m}$ above sea level. The climate is typically Mediterranean: The annual rainfall is $579 \mathrm{~mm}$, and the mean annual temperature is $16^{\circ} \mathrm{C}$. Dry and hot summers with a mean temperature of $25.7^{\circ} \mathrm{C}$ and $8 \mathrm{~mm}$ of precipitation in July contrast with cool, rainy winters with a mean temperature of $7.6^{\circ} \mathrm{C}$ and $73 \mathrm{~mm}$ of precipitation in January. The landscape is dominated by open dehesas and by deforested grazing pastures and croplands. The prevailing soils are chromic luvisols and eutric leptosols. Mediterranean holm oak (Quercus ilex ballota) is the dominant tree species in the dehesas of Monroy and is only occasionally accompanied by wild olive trees (Olea europaea var. sylvestris), wild pears (Pyrus bourgaeana), and cork oaks $(Q$. suber). 
Fig. 2. Sheep grazing in a dehesa with scattered holm oaks (Parapuños de Doña María site, April 2007). Obviously, tree regeneration is almost nonexistent.

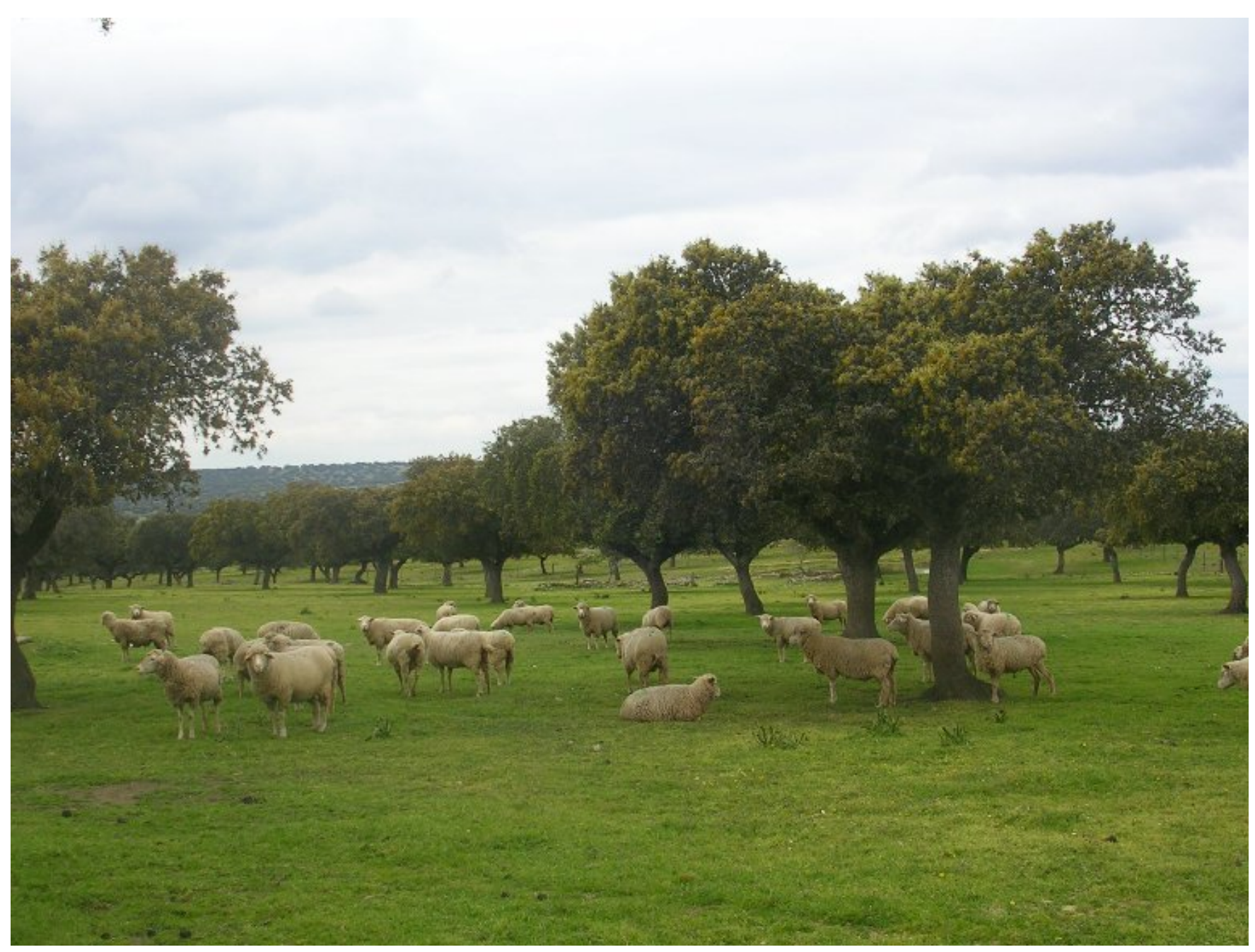

Agricultural statistics indicate that livestock stocking levels and the extent of land dedicated to crop production have changed considerably in Monroy. Stocking densities decreased slightly between 1950 and 1982, with values of about 0.15 livestock units (LU) per hectare of utilized agricultural area (1950: 4000 LU/ha, 1955: 3369 LU/ha, 1982: $2930 \mathrm{LU} / \mathrm{ha}$ in absolute terms). In the following years, however, these densities rose to 0.36 LU/ha (1989: 3440 LU, 1998: 7920 LU). The composition of the four dominant livestock species also changed: Sheep and pigs, the traditional animals of the dehesa, represented 39 and $40 \%$ of livestock, respectively, in 1955, but these percentages decreased to 28 and 7 in 1998. In contrast, cattle increased from 16 to $57 \%$, and goats from 5 to $8 \%$. The amount of cultivated land expanded dramatically from 2885 ha in 1960 to 4472 ha in 1976 . Later, the amount of farmland was reduced to less than the amount under cultivation in 1960 (1982: 2084 ha, 1989: 1371 ha, 1998: 1483 ha, 2003: 1122 ha).

The PA site (119 ha) is situated within a privately owned 798-ha estate. Land uses in 2002 were husbandry of 1450 Entrefina ewes, 150 goats, and 
150 indigenous Cerdo ibérico hogs. Current livestock stocking levels are 0.298 LU/ha. The estate is managed by one full-time employee and one goat keeper. Until the beginning of the 1980s, nearly 600 ha of the estate experienced extensive cultivation of crops in three-year cycles, interrupted by fallow periods.

The DB site (255 ha; Fig. 2) is part of a 550-ha dehesa estate. Historically, tenure of the pasture and trees, the so-called "suelo" and "vuelo," was divided. The right of pasture grazing was held by the community of local citizens, whereas specific individuals or families were entitled to use acorns and firewood from the trees. In the 1980s, tree ownership was expropriated and transferred to the regional government. Nowadays the Monroy town administration allows every local inhabitant to put a certain number of livestock on the land. In 2003, the estate was grazed by 159 cattle, mainly the introduced Charolais breed; 150 hogs, mainly the introduced Duroc Jersey breed; 161 goats; 20 horses; and seven donkeys from a total of about 80 owners. Livestock stocking levels are $0.484 \mathrm{LU} / \mathrm{ha}$. The DB estate has always been used exclusively for livestock grazing and never for crop cultivation.

\section{METHODS}

We decided on an in-depth study on two estates rather than a less intensive analysis of a larger number of areas. The intensive approach improved both the accuracy of the analyzed data, because we were able to visit the estates various times for detailed ground truthing, and the spatial overlap of forest-stand and land-use data because land managers could be interviewed in detail and extensive historical information was available. However, because the focus on two estates had the potential to weaken the explanatory power of the study, we chose to present potential explanations rather than provide confirmed answers and to embed our results into other recent findings on the mechanism of holm oak (Quercus ilex) regeneration in dehesas. The study was intended to act as a departure point for complementary remote sensing studies of forest stand dynamics on a larger geographic scale.

This study drew on satellite imagery and aerial photography as primary data sources. In Spain, national aerial photograph surveys were performed in 1956, 1984, and 1996, although the latter series was not used in this study because more recent satellite images were available. At each of the two sites, the presence of holm oaks was noted and recorded by photo interpretation of black-and-white photographs and satellite imagery corresponding to aerial photographs for the years 1956 and 1984 and a satellite image from the year 2003.

\section{Satellite image processing}

High-resolution panchromatic and multispectral QuickBird images of the study area were taken on 10 March 2003 (geometric accuracy: $23 \mathrm{~m}$, off-nadir deviation: $13.2^{\circ}$ ). The panchromatic satellite image had $11,992 \times 7156$ pixels (grayscale/16 bit), and the multispectral image had 2998 x 1789 pixels (RGB/16 bit). The ortho-rectified images were available as Universal Transverse Mercator map projections (WGS 84) in a GeoTIFF-Format. The images were recalculated from 16 to 8 bits to minimize file size. This smaller file size was sufficient for a visual interpretation of the Quercus ilex trees in the image and allowed us to use the images on location with a laptop and a personal digital assistant with the application ArcPAD. Both images were merged in Adobe Photoshop to integrate the high-resolution properties of the panchromatic image into the multispectral image (Albertz 2001). For this, both raster files were transformed into the Lab modus, a color model different from RGB that describes colors by a luminance component and two chromatic components $(\mathrm{a}=\mathrm{red} /$ green $\mathrm{axis}$ and $\mathrm{b}=$ blue/yellow axis). The radiometrically processed satellite image was then geometrically edited using ERDAS IMAGINE 8.7 (ERDAS Inc., Atlanta, Georgia, USA). With the aid of 19 ground control points, an accuracy of 0.51-m root mean square was achieved.

\section{Aerial photograph processing}

Both the 1956 and 1984 photographs, which measured $23 \times 23 \mathrm{~cm}$, had a scale of about 1:30,000 and were panchromatic black and white. The 1956 picture was provided by Spain's Centro Cartográfico y Fotográfico del Ejército del Aire, the 1984 picture from the Spanish Centro Nacional de Información Geográfica. The photographs were digitally scanned at a resolution of $400 \mathrm{dpi}$. Contrast and brightness was modified in ArcGis Desktop 9.1 (ESRI, Redlands, California, USA) to facilitate tree 
Table 1. Criteria table for the three-date image processing showing changes in tree numbers.

\begin{tabular}{llll}
\hline \hline Code $^{\dagger}$ & Oldest image & Middle image & Latest image \\
\hline 1 & Tree visible (T) & Tree visible (T) & Tree visible (T) \\
2 & Tree visible (T) & Tree visible (T) & Tree missing (NT) \\
3 & Tree visible (T) & Tree missing (NT) & Tree missing (NT) \\
4 & Tree missing (NT) & Tree visible (T) & Tree visible (T) \\
5 & Tree missing (NT) & Tree missing (NT) & Tree visible (T) \\
\hline
\end{tabular}

${ }^{\dagger}$ Pathways T - NT $-\mathrm{T}$ and NT $-\mathrm{T}-\mathrm{NT}$ were not considered.

identification. Geometric editing was done by comparing landmarks between the ortho-rectified satellite image and the aerial photographs. The same control points were used in the two photographs and the satellite image by working with two viewers in the Geo Correction Tool.

\section{Measurement and analysis}

A geo-information system was built up in the ArcCatalog and ArcMap packages of ArcGis Desktop 9.1 to analyze changes in stand structure in terms of direction and rate. To do this, trees were identified and interpreted from each image on a physiognomic basis, and individual trees were labeled as a point feature class in the GIS database. Field work in spring 2005 confirmed that trees were accurately identified from the 2003 image. The threshold for a tree to be included in the analysis was a crown diameter of 5-6 m. Trees were attributed according to a criteria table (Table 1) similar to that of Mast et al. (1997). Table 2 presents the distribution of change classes found. Recruitment rates were calculated by dividing the number of newly visible trees by the total number of trees counted in the previous census. The mortality rate was defined as the number of missing trees divided by the total number of trees counted in the previous census. Total recruitment and mortality rates were divided by the time intervals between censuses to determine mean annual recruitment and mortality rates. We tested the distribution of 1956 and 2003 trees and of trees lost between 1956 and 2003 for spatial randomness using $T^{2}$ data (Sutherland 2006). The spatial distribution of these objects $(m=100 * 2$ estates $*$ 3 objects) was analyzed by calculating $t_{\mathrm{N}}$ values:

$$
t_{N}=m^{-1} \sum\left[\frac{x_{i}^{2}}{\left(x_{i}^{2}+0.5 z_{i}^{2}\right)}\right]
$$

where $m$ is the number of samples, $x_{\mathrm{i}}$ equals pointobject distances in meters, and $z_{\mathrm{i}}$ equals objectobject distances in meters. Spatially random distribution means that $t_{\mathrm{N}}$ is normally distributed with a mean of 0.5 and a variance of $(12 \mathrm{~m})^{-1}$. Significant deviations of $t_{\mathrm{N}}$ from expected values for spatially random patterns were tested by converting $t_{\mathrm{N}}$ to $z$ scores and computing a corresponding $P$ value.

\section{RESULTS}

Some general land-use observations could be drawn from the images. At the Dehesa Boyal (DB) site, the apparent pattern of land use remained unchanged during the period studied. At the Parapuños de Doña María (PA) site, rotational crop cultivation could be detected in 1956 and 1984, whereas in 2003 the area 
Table 2. Distribution of change categories. T stands for "visible tree," and NT stands for "tree missing." The DB site is the Dehesa Boyal site, and the PA site is the Parapuños de Doña María site..

\begin{tabular}{lcccc}
\hline \hline & \multicolumn{2}{c}{ DB site } & \multicolumn{2}{c}{ PA site } \\
\cline { 2 - 5 } & Number of trees & Percent & Number of trees & Percent \\
\hline T-T-T & 6010 & $97.1 \%$ & 2392 & $62.8 \%$ \\
T-T-NT & 63 & $1.0 \%$ & 100 & $2.6 \%$ \\
T-NT-NT & 107 & $1.7 \%$ & 1262 & $33.1 \%$ \\
NT-T- T & 9 & $0.1 \%$ & 34 & $0.9 \%$ \\
NT-NT-T & 3 & $0.0 \%$ & 21 & $0.6 \%$ \\
\hline
\end{tabular}

was exclusively dedicated to grazing. In the DB site there was also evidence of holm oak (Quercus ilex) seedlings planted in individual mesh cages. These plantations were reported to have started in about the year 2000, so that their impact on oak stand structure cannot yet be quantified.

\section{Stand densities and recruitment and mortality rates, 1956-2003}

Altogether, 6180 and 3754 trees at the DB and PA sites, respectively, were recorded in 1956; 6084 and 2526 were recorded in 1984; and 6022 and 2447 were recorded in 2003. Stand density has continually decreased from 1956 to 2003 at both the DB and PA sites (Table 3). With a total decrease of about $2.6 \%$, changes in the holm oak population at the DB site have been slight. In contrast, the PA site experienced a considerable total decrease $(34.8 \%)$ from 31.55 to 20.56 trees/ha. These changes can be tracked on two exemplary sections in Fig. 3. Table 4 shows the level of loss and recruitment within the two sites. At the DB site, approximately $2.75 \%$ of the trees were lost from 1956 to 2003 , resulting in an annual mortality rate of $0.06 \%$. At $0.02 \%$ of the 1956 rate (far less than $0.01 \% / y r$ ), the recruitment rate was more than 10 times lower than the loss rate. This resulted in an overall decline of $0.05 \%$ in tree density/yr. At the PA site, more than every third tree $(36.3 \%)$ disappeared in the same period $(0.77 \% / y r)$. The recruitment rate was $1.5 \%$, amounting to recruitment of $0.03 \% / \mathrm{yr}$. This results in an overall decline of $34.85(0.74 \% / y r)$, which is about 15 times higher than the overall decline at the DB site during the same period. Figures 4 and 5 show the spatial distribution of outlived, lost, and recruited trees.

\section{Spatial pattern of change, 1956-2003}

The 1956 oak stands deviated significantly from a random spatial pattern. A regular dispersion was indicated by $t_{\mathrm{N}}$ values of 0.40 at the DB site $(z=-3.23$ and $P<0.001)$ and 0.38 at the PA site $(z=-4.28, P$ $<0.001)$. Similar values were found for the 2003 stands (DB: $t_{\mathrm{N}}=0.38, z=-4.28, P<0.001$; PA: $t_{\mathrm{N}}$ $=0.38, z=-4.06, P<0.001)$. In contrast, the trees lost from 1956 to 2003 showed a random distribution (DB: $t_{\mathrm{N}}=0.55, z=1.73, P=0.08$; PA: $\left.t_{\mathrm{N}}=0.50, z=-0.70, P=0.48\right)$.

\section{Temporal dynamics of recruitment and mortality rates, 1956-2003}

Introducing additional information from the 1984 time layer, changes in tree density show little difference between 1956-1984 and 1984-2003 at the DB site, with an overall decline of 3.5 and 3.2 trees/yr for the two periods, respectively (Table 5). In contrast, the situation at the PA site altered dramatically between the two periods; the level of loss decreased from 1956-1984 (45.07 trees/yr) to 1984-2003(4.2 trees/yr). PA recruitment rates were quite similar, with 1.1-1.2 new trees/yr. 
Table 3. Changes in stand densities, 1956-2003. DB is the Dehesa Boyal site, and PA is the Parapuños de Doña María site.

\begin{tabular}{lcc}
\hline \hline & DB & PA \\
\hline Stand densities, 1956 & 24.23 trees/ha & 31.55 trees/ha \\
Stand densities, 1984 & 23.85 trees/ha & 21.23 trees/ha \\
Stand densities, 2003 & 23.61 trees/ha & 20.56 trees/ha \\
\hline
\end{tabular}

\section{DISCUSSION}

This study selected the dynamics of oak cover as a primary driver of landscape modification in dehesas. It illustrates a general trend of decreased tree density from the 1950s onwards. At the Dehesa Boyal (DB) site, this decrease was slight; at the Parapuños de Doña María (PA) site, it was marked. If we assume that the PA site, with stand density losses of $34.8 \%$ from 1956 to 2003, is typical of the dominant private dehesa estates, and ElenaRosselló et al. (1987) found a similarly high tree loss rate $(23 \%)$ over the whole of Extremadura, then the impact, in terms of the absolute number of lost oaks, of the gradual regression of trees might be similar to the outright destruction of oaks by land conversion. For example, losses of dehesa surface were estimated at 9.6\% during the period 19571981 in Extremadura (Elena-Rosselló et al. 1987), 24\% from 1950 to 1984 in the Sierra Morena (Fernández-Ales et al. 1992), 20-25\% from 1956 to 1977 in the Sierra Norte (Joffre et al. 1988), and 40\% from 1955 to 1981 in all of Spain (FernándezRebollo and Porras-Tejeiro 1999), although regional variability is generally large (RegatoPajares et al. 2004).

The aim of this study was to interpret secondary processes in nested scales of explanation (Bürgi et al. 2004), i.e., the opposite processes of tree recruitment and mortality. The recruitment rate was continuous but very low in both cases, with only < 0.01 and $0.03 \%$ of the tree density recruited per year. The length of the rotation period necessary for the complete regeneration of holm oak (Quercus ilex) is a controversial matter. The biological longevity of holm oak is estimated at $250 \mathrm{yr}$ (Ruiz-Pérez 1986), but individual holm oaks can live up to 700 yr or longer (Ruiz-de-la-Torre 1984). However, the "useful life-span" is considerably shorter, because the age of holm oaks in dehesas is generally not limited by their biological life-span but by land management (Grove and Rackham 2001). Montero et al. (1998) assumed a necessary rotation period of $120 \mathrm{yr}$. Assuming a rotation period of $200 \mathrm{yr}$, an annual recruitment of $1 / 200=0.50 \%$ of tree density would be necessary for the long-term persistence of the stands. This confirms other findings that current recruitment is too low by a factor of between 10 and 50 to maintain existing stand densities (Plieninger et al. 2004, Pulido and Díaz 2005). Even if we assume a useful life of $300 \mathrm{yr}$, levels of necessary annual recruitment $(0.33 \%)$ would not be met. Recruitment rates were obviously not compensating for the loss rate at either site. At the DB site, mortality has been moderate, whereas at the PA site it has been dramatic, with $36 \%$ of the original tree density lost. Although the spatial pattern of oak stands was highly regular, the trees lost from 1956 to 2003 were randomly spaced. The uniform pattern of widely spaced stands suggests that 1956-2003 tree mortality has been the result of direct human management rather than unintended degeneration, although tree spacing is, on a larger spatial scale, also controlled by annual rainfall (Joffre et al. 1999). Tree spacing by selection and thinning has been performed in many dehesas to bring up wide crowns (Pulido et al. 2001). Research has shown that trees benefit from this type of management, as indicated by their improved nutritional and physiological status, faster growth, and higher productivity (Infante et al. 1999, Moreno-Marcos et al. 2007). Among the reasons for stand thinning and land plowing may be improved acorn production, pasture quality, and farm accessibility (Pulido et al. 2001, Moreno-Marcos et al. 2007). 
Table 4. Total number and percentage of trees lost and recruited in the Dehesa Boyal (DB) and Parapuños de Doña María (PA) sites, 1956-2003.

\begin{tabular}{|c|c|c|c|c|}
\hline & $\begin{array}{c}\text { Total number of } \\
\text { trees }\end{array}$ & $\begin{array}{l}\text { Percentage of } 1956 \\
\text { tree cover }\end{array}$ & $\begin{array}{l}\text { Number of trees per } \\
\text { year }\end{array}$ & $\begin{array}{l}\text { Percentage of } 1956 \text { tree } \\
\text { cover per year }\end{array}$ \\
\hline \multicolumn{5}{|l|}{ DB } \\
\hline Trees 1956 & 6180 & & & \\
\hline $\begin{array}{l}\text { Lost between } \\
1956 \text { and } 2003\end{array}$ & 170 & $2.75 \%$ & 3.47 & $0.06 \%$ \\
\hline $\begin{array}{l}\text { Recruited between } \\
1956 \text { and } 2003\end{array}$ & 12 & $0.02 \%$ & 0.24 & $<0.01 \%$ \\
\hline Trees 2003 & 6022 & & & \\
\hline Overall loss, 1956-2003 & 158 & $2.56 \%$ & 3.22 & $0.05 \%$ \\
\hline \multicolumn{5}{|l|}{ PA } \\
\hline Trees 1956 & 3754 & & & \\
\hline $\begin{array}{l}\text { Lost between } \\
1956 \text { and } 2003\end{array}$ & 1362 & $36.28 \%$ & 28.98 & $0.77 \%$ \\
\hline $\begin{array}{l}\text { Recruited between } \\
1956 \text { and } 2003\end{array}$ & 55 & $1.47 \%$ & 1.17 & $0.03 \%$ \\
\hline Trees 2003 & 2447 & & & \\
\hline Overall loss, 1956-2003 & 1307 & $34.82 \%$ & 27.81 & $0.74 \%$ \\
\hline
\end{tabular}

The driving forces of land cover modification can be discussed along two axes: (1) a comparison of the two sites helps us understand the effects of land ownership on dehesa management and forest-stand dynamics, e.g., different use intensities or different permanence of certain land-use practices; and (2) a comparison of three time layers may explain the respective impact of political and economic paradigms, e.g., the dehesa legislation or agricultural support schemes of a given era.

Stand dynamics varied distinctly between the community-owned DB and the privately owned PA sites. Possibly because of a longer and more intensive history of grazing, stand densities at the DB site were about $30 \%$ lower than those at the PA site in 1956. The 1956-2003 recruitment rate was slightly higher at the latter than the former. A potential explanation suggests that heavy grazing on the DB site prevented recruitment to a stronger extent than at the PA site, at which a lower grazing pressure prevailed over the past decades. This would seem to validate the classical viewpoint of the "tragedy of the commons" (Hardin 1968), which alleges that common-property systems have an inherent logic that inevitably leads to overgrazing beyond the carrying capacity of the land. However, common property also turned out to be beneficial for forest stand conservation in this case. On the single private-ownership PA site, holm-oak mortality was much higher than on the DB site from 1956 to 2003 . At the PA site, oaks were cleared on a large scale to facilitate crop cultivation, especially from 1956 to 1984 . At the DB site, the multifaceted pattern of land tenure, which allocates the right of use, but not the right of destruction, of the oak trees to a multitude of beneficiaries, has acted as a barrier to forest clearing. 
Fig. 3. Comparison of stand development 1956 (left), 1984 (center), and 2003 (right) of a Dehesa Boyal (DB) section (above) and a Parapuños de Doña María (PA) section (below).

\section{DB section}

\section{6}

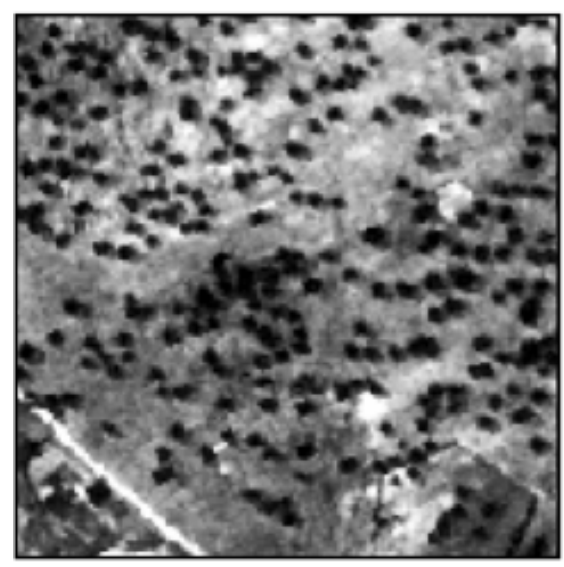

1984

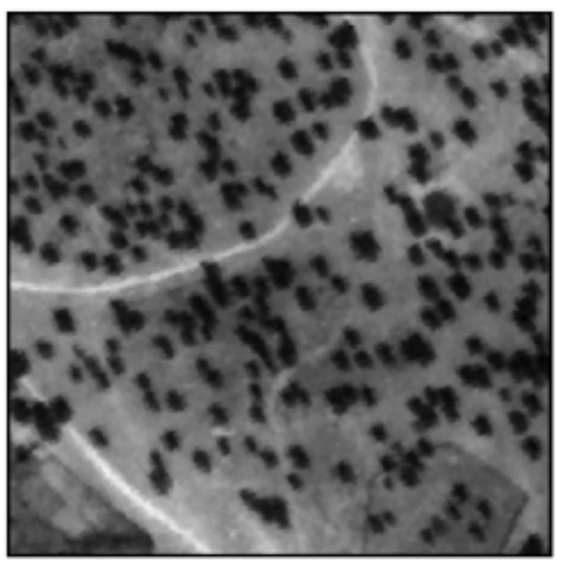

2003

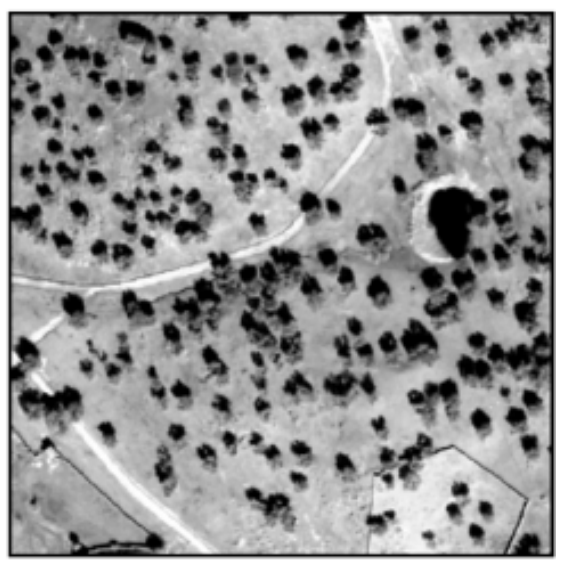

\section{PA section}

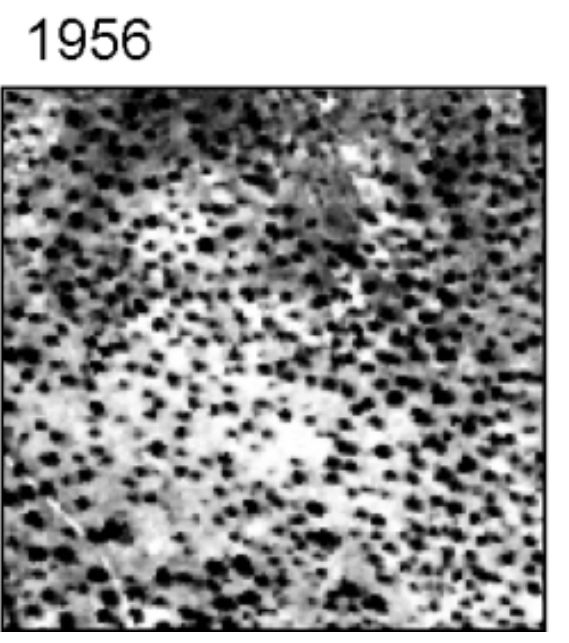

1984

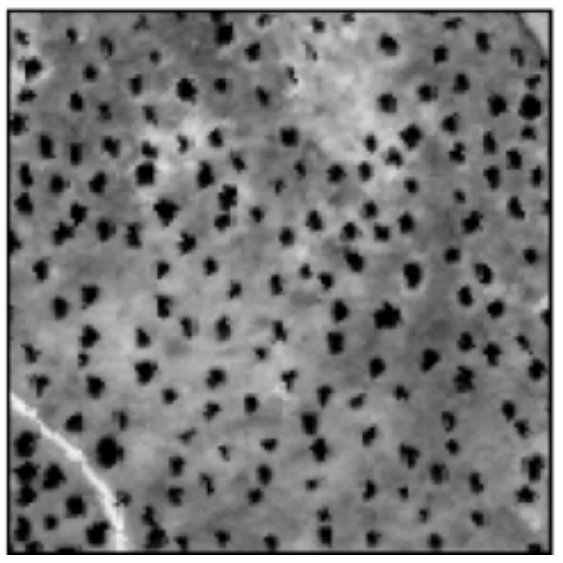

2003

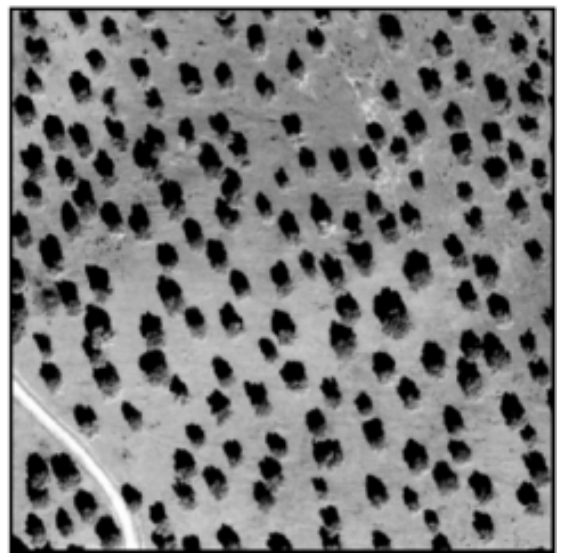

The use of three temporal layers allowed a broad match of recruitment and mortality events to two different spaces of time. However, additional time layers would be needed for the specific timing of these events and for an exact calculation of process pace. This study showed an apparent temporal pattern: Tree recruitment rates decreased slightly from the 1956-1984 to the 1984-2003 period. In contrast, mortality at the PA site was extremely high in the former period but decreased to less than a tenth of that rate in the latter period. This indicates that the problem of high mortality, at least that resulting from deliberate tree felling, may have been met effectively, but that regeneration failure still remains unresolved and has even been aggravated. This result agrees with broader land-cover change 
Fig. 4. Spatial distribution of outlived, lost, and recruited trees at the Dehesa Boyal site, 1956-2003.

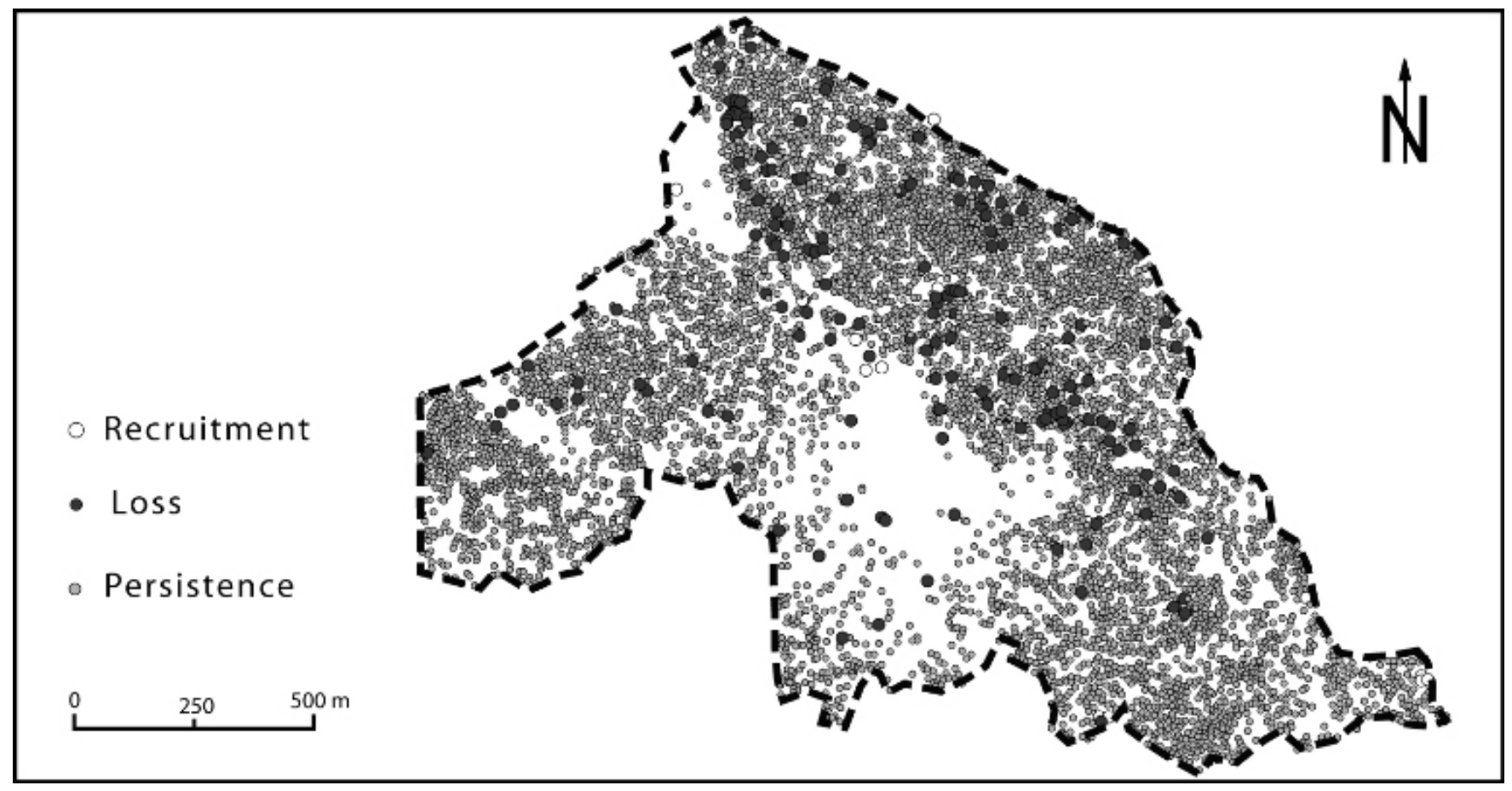

analyses that identified a period of outright destruction of dehesas in 1956-1984 and a period of land abandonment in 1984-2003 (LavadoContador et al. 2004, Plieninger 2006). The slight decrease in regeneration from 1984 to 2003 might be related to the strong increase in livestock stocking levels from the 1980s onward, although it is difficult to establish a direct relationship between grazing pressure and regeneration success (Plieninger et al. 2004). The strong mortality from 1956 to 1984 was probably caused by the agricultural modernization and mechanization that prevailed in Spain during that era. For example, oaks were frequently cleared to open the land for tractors (Díaz et al. 1997, Pulido et al. 2001). One reason why deliberate felling was largely abandoned from 1984 onward might be the 1986 enactment of the "dehesa law" in Extremadura, which put cutting of holm oaks under strict government control. The large-scale abandonment of crop cultivation and the related soil tillage since that time might also have contributed to the reduction in oak mortality. Using the conceptual model of temporal trajectories offered by Bürgi et al. (2004), we conclude that the phenomenon of tree loss was an isolated rapid change in the 1956-1984 period. Since then, change has clearly decelerated but is still continuing. Whereas the lack of recruitment was accidental, the loss of oaks through clearing was mostly intentional. However, with more and more oaks approaching the end of their natural life, the loss of oaks might also become a largely unintended process.

The future trajectory of forest-stand dynamics in dehesas remains open. On the one hand, the period of large-scale destruction of holm oaks seems clearly over. On the other hand, the phenomenon of sudden oak death caused by a complex disease related to the Phytophtora cinnamomi pathogen has caused increased mortality locally (Gallego et al. 1999). A further challenge for the largely monospecific dehesas will be to tackle predicted temperature and precipitation changes (Joffre et al. 1999). Moreover, natural recruitment is far too low, and the success of ongoing afforestation schemes is questionable at best. Therefore, the window of opportunity for balancing holm oak recruitment and mortality is tight (Manning et al. 2006). 
Fig. 5. Spatial distribution of outlived, lost, and recruited trees at the Parapuños de Doña María site, 1956-2003.

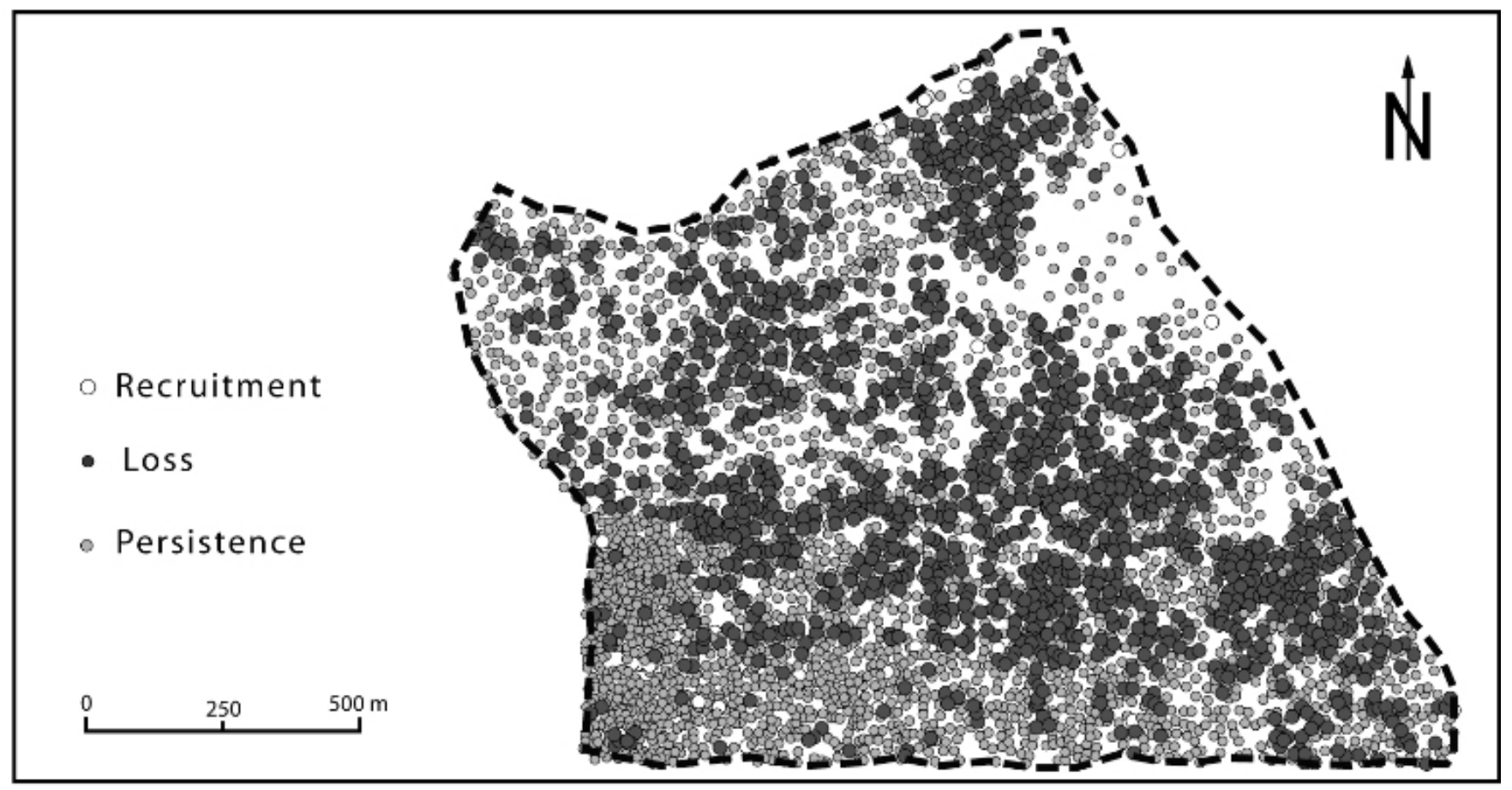

\section{CONCLUSION}

Changes in land management, such as the uprooting of trees or the abandonment of traditional crop cultivation, trigger land-cover changes that can be detected through large-scale monitoring. Such assessments, however, tend to ignore small-scale structural modifications within a single land-cover unit. In the case of dehesas, the most influential landscape change is the gradual dissolution of holm oak (Quercus ilex) stands. Remote sensing analysis made it possible to track the life histories of the individual oak trees in a dehesa. It confirmed the hypothesis of stand dissolution resulting from both increased mortality and the insufficient establishment of oak seedlings and saplings. Similar evaluations could include the loss of other linear and point key elements of traditional landscapes, e.g., scattered fruit trees, hedgerows, ditches, field margins, farmsteads, stone walls, terraces, or drovers' roads. The analysis of oak expansion and regression as a precursor of land conversion can provide a powerful tool for subtle structural changes. Similar assessments could be applied to agroforestry systems comparable to dehesas, e.g., traditional olive cultivation, chestnut groves, and oak rangelands in Italy, Greece, southern France, and especially the islands of Sardinia, Corsica, and Crete. If upscaled on a larger area, they can be used as an early warning system before conversion becomes visible. This requires the use of automatic or semi-automatic procedures that extract single trees form remote sensing imagery. Still, given that many traditional agricultural landscapes in Europe are highly diverse, specific procedures will have to be developed for each particular landscape or landuse system.

Responses to this article can be read online at: http://www.ecologyandsociety.org/voll3/iss2/art25/responses/ 
Table 5. Total number of trees lost and recruited, 1956-1984, 1984-2003, and 1956-2003. DB is the Dehesa Boyal site, and PA is the Parapuños de Doña María site.

\begin{tabular}{llc}
\hline \hline & DB & PA \\
\hline Number of trees lost between 1956 and 1984 per year & 3.82 & 45.07 \\
Number of trees lost between 1984 and 2003 per year & 3.32 & 5.26 \\
Number of trees recruited between 1956 and 1984 per year & 0.32 & 1.21 \\
Number of trees recruited between 1984 and 2003 per year & 0.16 & 1.11 \\
Total tree losses per year, 1956-1984 & 3.50 & 43.86 \\
Total tree losses per year, 1984-2003 & 3.16 & 4.15 \\
\hline
\end{tabular}

\section{Acknowledgments:}

The authors thank B. Meißner and M. Meißner for providing the satellite image and for their valuable technical advice. The advice of two anonymous referees is greatly appreciated.

\section{LITERATURE CITED}

Albertz, J. 2001. Einführung in die Fernerkundung. Wissenschaftliche Buchgesellschaft, Darmstadt, Germany.

Antrop, M. 1997. The concept of traditional landscapes as a base for landscape evaluation and planning: the example of Flanders region. Landscape and Urban Planning 38:105-117.

Antrop, M. 2004. Landscape change and the urbanization process in Europe. Landscape and Urban Planning 67:9-26.

Bignal, E. M., and D. I. McCracken. 1996. Lowintensity farming systems in the conservation of the countryside. Journal of Applied Ecology 33:413-424.

Brandt, J., J. Primdahl, and A. Reenberg. 1999. Rural land-use and dynamic forces: analysis of "driving forces" in space and time. Pages 81-102 in
R. Kronert, J. Baudry, I. R. Bowler, and A. Reenberg, editors. Land-use changes and their environmental impact in rural areas in Europe. UNESCO, Paris, France.

Bunce, R. G. H., G. B. Groom, R. H. G. Jongman, and E. Padoa-Schioppa. 2005. Handbook for surveillance and monitoring of European habitats. Alterra-rapport 1219. Alterra, Wageningen, The Netherlands.

Bürgi, M., A. M. Hersperger, and N. Schneeberger. 2004. Driving forces of landscape change: current and new directions. Landscape Ecology 19:857-868.

Calvo-Iglesias, M. S., U. Fra-Paleo, R. CrecenteMaseda, and R. A. Diaz-Varela. 2006. Directions of change in land cover and landscape patterns from 1957 to 2000 in agricultural landscapes in NW Spain. Environmental Management 38:921-933.

Campos-Palacín, P. 1984. Economía y energía en la dehesa extremeña. Instituto de Estudios Agrarios, Pesqueros y Alimentarios, Madrid, Spain.

Comins, J. S., J. B. Sendra, and F. M. Sanz. 1993. Crisis and permanence of the traditional Mediterranean landscape in the central region of Spain. Landscape and Urban Planning 23:155-166.

Díaz, M., P. Campos, and F. J. Pulido. 1997. The Spanish dehesas: a diversity in land-use and 
wildlife. Pages 178-209 in D. J. Pain and M. W. Pienkowski, editors. Farming and birds in Europe; the Common Agricultural Policy and its implications for bird conservation. Academic Press, London, UK.

Díaz, M., F. J. Pulido, and T. Marañón. 2003. Diversidad biológica y sostenibilidad ecológica y económica de los sistemas adehesados. Ecosistemas 12 (3). Available online at http://www.revistaecosistemas. net/index frame.asp?pagina $=\mathrm{http} \% 3 \mathrm{~A} / \mathrm{www}$. revistaecosistemas.net/articulo.asp\%3FId\%3D193

Eichhorn, M. P., P. Paris, F. Herzog, L. D. Incoll, F. Liagre, K. Mantzanas, M. Mayus, G. Moreno, V.P. Papanastasis, D. J. Pilbeam, A. Pisanelli, and C. Dupraz. 2006. Silvoarable systems in Europe: past, present and future prospects. Agroforestry Systems 67:29-50.

Elena-Rosselló, M., J. A. López-Márquez, M. Casas-Martín, and A. Sánchez-del-Corral Jiménez. 1987. El carbón de encina y la dehesa. Instituto Nacional de Investigaciones Agrarias, Madrid, Spain.

Feranec, J., G. Hazeu, S. Christensen, and G. Jaffrain. 2007. Corine land cover change detection in Europe (case studies of the Netherlands and Slovakia). Land Use Policy 24:234-247.

Fernández-Ales, R., A. Martín, F. Ortega, and E. E. Ales. 1992. Recent changes in landscape structure and function in a Mediterranean region of southwest Spain (1950-1984). Landscape Ecology 7:3-18.

Fernández-Rebollo, P., and C. J. Porras-Tejeiro. 1999. La dehesa, algunos aspectos para la regeneración del arbolado; informaciones técnicas 58/59. Conserjeróa de Agricultura y Pesca, Junta de Andalucóa, Sevilla, Spain.

Gallego, F. J., A. P. de Algaba, and R. FernándezEscobar. 1999. Etiology of oak decline in Spain. European Journal of Forest Pathology 29:17-27.

Grove, A. T., and O. Rackham. 2001. The nature of Mediterranean Europe: an ecological history. Yale University Press, New Haven, Connecticut, USA.

Hardin, G. 1968. The tragedy of the commons. Science 162: 1243-1248.
Harrop, S. R. 2007. Traditional agricultural landscapes as protected areas in international law and policy. Agriculture, Ecosystems and Environment 121:296-307.

Infante, J. M., C. Damesin, S. Rambal, and R. Fernández-Ales. 1999. Modelling leaf gas exchange in holm-oak trees in southern Spain. Agricultural and Forest Meteorology 95:203-223.

Jansen, L. J. M., and A. Di-Gregorio. 2002. Parametric land cover and land-use classifications as tools for environmental change detection. Agriculture, Ecosystems \& Environment 91:89-100.

Joffre, R., S. Rambal, and J. P. Ratte. 1999. The dehesa system of southern Spain and Portugal as a natural ecosystem mimic. Agroforestry Systems 45:57-79.

Joffre, R., J. Vacher, C. de-los-Llanos, and G. Long. 1988. The dehesa: an agrosilvopastoral system of the Mediterranean region with special reference to the Sierra Morena area of Spain. Agroforestry Systems 6:71-96.

Kizos, T., and M. Koulouri. 2008. Same land cover, same land use at large scale, different landscapes at the small scale: landscape change in olive plantations on Lesvos Island, Greece. Landscape Research 33:in press.

Klijn, J., and W. Vos. 2000. From landscape ecology to landscape science. Kluwer Academic, Wageningen, The Netherlands.

Kristensen, S. P. 1999. Agricultural land and landscape changes in Rostrup, Denmark: process of intensification and extensification. Landscape and Urban Planning 46:117-123.

Lavado-Contador, J. F., S. Schnabel, and R. Trenado-Ordóñez. 2004. Comparison of recent land use and land cover changes in two dehesa agrosilvopastoral landuse systems, SW Spain. Advances in Geoecology 37:55-69.

Linares-Luján, A. M., and S. Zapata-Blanco. 2002. Una visión panorámica de ocho siglos. Pages 13-25 in F. J. Pulido, P. Campos, and G. Montero, editors. La gestión forestal de las dehesas. Instituto del Corcho, la Madera y el Carbón, Môrida, Spain.

Manning, A., J. Fischer, and D. Lindenmayer. 
2006. Scattered trees are keystone structures: implications for conservation. Biological

Conservation 132:311-321.

Mast, J. N., T. T. Veblen, and M. E. Hodgson. 1997. Tree invasion within a pine/grassland ecotone: an approach with historical aerial photography and GIS modeling. Forest Ecology and Management 93:181-194.

Meeus, J. H. A. 1995. Pan-European landscapes. Landscape and Urban Planning 31:57-79.

Meeus, J. H. A., M. P. Wijermans, and M. J. Vroom. 1990. Agricultural landscapes in Europe and their transformation. Landscape and Urban Planning 18:289-352.

Montero, G., A. San-Miguel, and I. Cañellas. 1998. Sistemas de selvicultura mediterránea: la dehesa. Pages 519-554 in R. Jiménez Díaz, and J. Lamo de Espinosa, editors. Agricultura sostenible. Ediciones Mundi-Prensa, Madrid, Spain.

Moreno, G., J. J. Obrador, and A. Garcia. 2007. Impact of evergreen oaks on soil fertility and crop production in intercropped dehesas. Agriculture Ecosystems \& Environment 119:270-280.

Moreno-Marcos, G., J. J. Obrador, E. García, E. Cubera, M. J. Montero, F. J. Pulido, and C. Dupraz. 2007. Driving competitive and facilitative interactions in oak dehesas through management practices. Agroforestry Systems 70:25-40.

Pereira, P. M., and M. P. da-Fonseca. 2003. Nature vs. nurture: the making of the montado ecosystem. Conservation Ecology 7(3): 7. [online] URL: http:/ /www.consecol.org/vol7/iss3/art7/.

Pérez-Díaz, A. 1993. Evolución, dificultades y perspectivas de la ganadería extremeña. Pages 183-199 in Asamblea de Extremadura, editor. Trashumancia y cultura pastoril en Extremadura. Asamblea de Extremadura, Departamento de Publicaciones, Mérida, Spain.

Pinto-Correia, T., and J. Mascarenhas. 1999. Contribution to the extensification/intensification debate: new trends in the Portuguese montado. Landscape and Urban Planning 46:125-131.

Plieninger, T. 2006. Habitat loss, fragmentation, and alteration: quantifying the impact of land-use changes on a Spanish dehesa landscape by use of aerial photography and GIS. Landscape

Ecology 21:91-105.

Plieninger, T., F. Höchtl, and T. Spek. 2006. Traditional land-use and nature conservation in European rural landscapes. Environmental Science \& Policy 9:317-321.

Plieninger, T., F. J. Pulido, and W. Konold. 2003. Effects of land use history on size structure of holm oak stands in Spanish dehesas: implications for conservation and restoration. Environmental Conservation 30:61-70.

Plieninger, T., F. J. Pulido, and H. Schaich. 2004. Effects of land-use and landscape structure on holm oak recruitment and regeneration at farm level in Quercus ilex L. dehesas. Journal of Arid Environments 57:345-364.

Poudevigne, I., and D. Alard. 1997. Landscape and agricultural patterns in rural areas: a case study in the Brionne basin, Normandy, France. Journal of Environmental Management 50:335-349.

Pulido, F. J., P. Campos, and G. Montero. 2002. La gestión forestal de las dehesas. Instituto del Corcho, la Madera y el Carbón, Mérida, Spain.

Pulido, F. J., and M. Díaz. 2005. Regeneration of a Mediterranean oak: a whole cycle approach. Ecoscience 12:92-102.

Pulido, F. J., M. Díaz, and S. Hidalgo-de-Trucios. 2001. Size-structure and regeneration of Spanish holm oak Quercus ilex forests and dehesas: effects of agroforestry use on their long-term sustainability. Forest Ecology \& Management 146:1-13.

Regato-Pajares, P., S. Jiménez-Caballero, M. Castejón, and R. Elena-Roselló. 2004. Recent landscape evolution in dehesa woodlands of Western Spain. Pages 57-72 in S. Mazzoleni, G. di Pasquale, M. Mulligan, P. di Martina, and F. Rego, editors. Recent dynamics of the Mediterranean vegetation and landscape. John Wiley, Hoboken, New Jersey, USA.

Rindfuss, R. R., S. J. Walsh, B. L. Turner, J. Fox, and V. Mishra. 2004. Developing a science of land change: challenges and methodological issues. Proceedings of the National Academy of Sciences of the United States of America 101:13976-13981. 
Ruiz-de-la-Torre, J. 1984. Arboles y arbustos de España. Salvat, Barcelona, Spain.

Ruiz-Pérez, M. 1986. Sustainable food and energy production in the Spanish "dehesa." UN Food and Energy Nexus Programme, Department of Ecology, Universidad Autónoma de Madrid, Madrid, Spain.

Sevenant, M., and M. Antrop. 2007. Assessing land use intensity and dynamics in a rural Mediterranean landscape: Lassithi Plateau in Crete. Pages 175-195 in Z. Roca, T. Spek, T. Terkenli, T. Plieninger, and F. Höchtl, editors. European landscapes and lifestyles: the Mediterranean and beyond. Edições Universitárias Lusofonas, Lisbon, Portugal.

Sutherland, W. J. 2006. Ecological census techniques. Cambridge University Press, Cambridge, UK. 